\title{
Blood ties: migrations, state transnationalism and automatic nationality
}

\author{
Sergio Caggiano
}

Centro de Investigaciones Sociales (CIS) - Consejo Nacional de Investigaciones Científicas y Técnicas (CONICET)/Instituto de Desarrollo Económico y Social (IDES), Buenos Aires, Argentina

\begin{abstract}
I propose contributing to the general understanding of the intricate relationship between nationality, citizenship and international migrations, focusing on the linkage or reincorporation policies of migrant-sending countries. Specifically, I will analyse a key change to the system for allocating Bolivian nationality by the Plurinational State of Bolivia and related measures during the presidency of Evo Morales, that is, the introduction of automatic jus sanguinis to maintain ties with emigrants. The automatic application of jus sanguinis abroad has theoretical implications on two different levels. One is the relationship between nationality and citizenship, specifically, that of the possible emancipation of citizenship from nationality. In this regard, the case I present reveals mechanisms that work in the opposite direction, binding citizenship to nationality. The second level is that of the potential expansion of ethno-nationalist or racialized conceptions of nationality.
\end{abstract}

ARTICLE HISTORY Received 8 January 2016; Accepted 6 June 2017

KEYWORDS Migration; state transnationalism; linkage policies; nationality; jus sanguinis; Bolivia

\section{Introduction}

In March 2012 I met with a high-ranking official at Bolivian Consular Affairs (DGAC, its Spanish acronym), the government office that oversees direct state contact with Bolivians abroad through country consulates. During our interview, half-joking and half serious, she said, "You're not allowed to use the term 'migrant' here." Her clarification reflected certain government measures at that time which had increasingly replaced the category of "migrant" with others, principally "residents abroad" or "Bolivians abroad". High-ranking state officials - like Bolivian President Evo Morales - also adopted this same approach. In a speech given on the 182nd anniversary of Bolivian independence, August 2007, Morales spoke of allowing "brothers and sisters who live abroad" to vote and then affirmed: "Those of you abroad 
guarantee our national unity" (quoted in Hinojosa Gordonava, Domenech, and Lafleur 2012, 52).

Many sending countries have changed the official categories used to refer to migration over the past few years. The replacement of the term "migrant" with phrases like "residents abroad" is important because of the state's critical role in producing the categories through which people experience their positions and relations (Hall 2003) as well as the attendant social classifications (Bourdieu 1982; Ortner 2006).

From its beginnings, the modern state and its nationality laws involved regulating people's movements across borders (Stolcke 1997), as human migration has implications for the notions of citizenship and nationality. The intensity of population movements today and debates on these movements have renewed interest in this topic. Some scholars have noted the fusion of citizenship, nationality, immigration policy and border control in recent years (Stolcke 1999; Joppke 2008).

I propose contributing to the general understanding of the intricate relationship between nationality, citizenship and international migrations, focusing on the linkage or reincorporation policies of migrant-sending countries. More precisely, I will analyse the actions and policies implemented by the Plurinational State of Bolivia (EPB, its Spanish acronym) during the presidency of Evo Morales from the Movement towards Socialism (MAS, its Spanish acronym). These include the enactment of the country's current constitution in 2009 and a key change to the system for allocating Bolivian nationality, that is, the introduction of automatic jus sanguinis to maintain ties with emigrants. My analysis will rest on what I consider the heuristic power of Foucault's proposal of governmentality and the production of population as foundational in modern states. I am particularly interested in the way in which this production of the population occurs, the rhetoric it develops, the mechanisms it features and the logics it sustains and consolidates.

The automatic application of jus sanguinis abroad has theoretical implications on two different levels. One is the relationship between nationality and citizenship, specifically, that of the possible emancipation of citizenship from nationality (Sassen 2002; Kivisto and Faist 2007). In this regard, the case I present reveals mechanisms that work in the opposite direction, binding citizenship to nationality. The other level is that of the eventual expansion of ethno-nationalist or racialized conceptions of nationality (Bauböck et al. 2006; Dumbrava 2015a). By fostering a certain concept of nationality, the policies I analyse reaffirm the bonds of blood and descent. Considering the international context in which this occurs, I intend to draw attention to the risk of permitting racialized conceptions of nation. ${ }^{1}$ 


\section{Transnational linkage, nationality and producing population abroad}

By calling those who have left Bolivia to live in another country "Bolivians abroad", the state expands its reach far beyond the country's borders. In the mid-1990s, similar decisions by other countries were referred to as "linkage policies", "transnational reincorporation policies" or "diaspora engagement policies" (Bauböck 2002; Guang and Debata 2010; van Dongen 2017). ${ }^{2}$ In research on transnational migration processes or "transmigration" some authors have supported the idea of a world order in which the notion of the state can no longer be conceptually limited to a certain geographical space, using terms such as "deterritorialised nations-states" (Basch, Schiller, and Blanc 1994; Solomon 2009) or "transnational nation-state" (Glick Schiller and Fouron 1999; Glick Schiller 2005). Given the state's increased involvement with those whom it defines as "our" populations or "our" citizens abroad, these studies note that some of the state's functions are being reformulated (Guarnizo and Smith 1998; Levitt and Glick Schiller 2004; Smith and Guarnizo 2009). Migrations represent both challenges and opportunities for state production and reproduction (Kalm 2008).

Although Foucault never directly addressed the topic of immigration, some of his works $(2006,2007)$ offer insights into the contemporary state dynamics associated with transnational migrations. ${ }^{3}$ In the first place, it is useful to recall the author's rhetorical question: "What if the state were nothing more than a way of governing?" $(2006,291)$ and a similar statement later in the same text, "The state is a practice [...] a way of doing things" (324). From this perspective, linkage and transnational reincorporation do not expand the state but instead remake it. Although there is no core state entity that defines the meaning and the aims of this reconstruction, the state is produced once again, or continuously produced, as the result of such processes. In fact, the state departments or offices that are responsible for such actions can be in conflict with one another or set on diverging courses. At the same time, the practices and actions of different departments establish mutual limits in a constant dialogue. $^{4}$

The population is the target of this "way of doing things", this set of practices and mechanisms, which create or produce population while at the same time reiterating the state as the entity entrusted with their regulation. The population, then, is a fundamental product of state interventions and also the basis for the state departments that produce it.

Additionally, Foucault argues that the technology of power that originated in the eighteen century highlights the question of circulation (of people, goods, symbols and knowledge). Sovereignty/territory, two paired notions during the previous period, give way to the paired notion security/circulation because if the conquest and control or preservation of a territory was what 
mattered until the Classic Age, the security of the population will become crucial in the new era, and circulation is critical to this security (Foucault 2006). In short, certain state bureaus and offices promote interventions to shape the population, the target and raison d'etre of the state, while dissociating it from territory.

From a different perspective, Stolcke notes that, "Of the three constitutive elements of the modern state, a territory, a government, a people, circumscribing the 'people' proved to be the most controversial issue" $(1997,61)$. During the formative period of modern nation state, determining the conditions for belonging to a state - or "bounding the citizenry" (Stolcke 1997, 61) represented a primordial and constitutive dilemma.

Discussions surrounding migration, states, globalization and transnationalism revealed how nationality and citizenship are often considered synonymous in legal terms. ${ }^{5}$ This subsumption of nationality and citizenship into a single indistinct status are linked with the conceptual difficulty of separating the formal requirements for acquiring citizenship (nationality) from the substantive rights that it entails, or "the conditions for and of membership in a nation-state" (Stolcke 1997, 62, emphasis is in the original), which can be followed in the subtle conceptual differences in recent classics on this topic (Brubaker 1992; Silverman 1992). Technically each term reflects a different legal framework - citizenship confined to the national dimension and nationality referring to the international legal dimension of an interstate system though both terms refer to the national state, identifying "the legal status of an individual in terms of state membership" (Sassen 2002, 7).

Sassen, however, also reflects on how these two categories have been historically viewed as synonymous. The legal bond between the individual and the polity, which narrowly defines citizenship, can assume different forms, depending on the definition of the polity. In ancient and medieval times, this polity was the city in Europe, and the evolution of polities along the lines of state formation made nationality a key component of citizenship. However, the last four decades of globalization, deterritorialization and post-nationalization have brought "conditions for a change in the institution of citizenship and its relation to nationality [...] The nationalizing of the institution, which took place over the last several centuries, may today give way to a partial denationalizing" (Sassen 2002, 8).

At the same time, mechanisms for the production of population like the one we will see here show that the dynamics of nationality and citizenship do not necessarily progress towards denationalization or the emancipation of citizenship from nationality (Kivisto and Faist 2007). Instead, interventions like those of the Bolivian state strengthen the ties between nationality and citizenship. This is not so much because Bolivian nationality is a constitutive element of Bolivian citizenship (though this is part), but because the 
automatic production of Bolivians abroad keeps some migrants from becoming citizens and exercising their rights in their places of residence.

\section{The Bolivian State and (automatic) "nationals abroad"}

The profound transformations that began during the Evo Morales administration included nationalizing strategic companies; implementing new social programmes along with economic policies aimed at the redistribution of wealth; defining Bolivia as a plurinational state comprised of thirty-six indigenous nations; modifying the regimen for land ownership; altering the forms of administering justice and establishing indigenous languages as official. Within the framework of these transformations, the government fostered an institutional dialogue with grassroots movements and social organizations, including associations of Bolivians abroad. The decision at the DGAC to avoid the term "migrant" when speaking of Bolivians abroad is part of this broader reorientation. Since Morales and the MAS party rose to power in 2006, international migration has been more important on Bolivia's political agenda than ever before (Domenech 2009).

This represented a break with a state that had, in the past, accepted its role as a receiving country and encouraged European immigration. The state's preoccupation with the loss of its population, however, reveals continuities between past and present. Governments with postures different or even at odds with that of Morales channelled this concern by requiring exit permits or requiring those who arrived to stay for a certain amount of time while encouraging those who had left to return (Domenech and Magliano 2007). The EPB took no measures that would limit the population flows abroad but the changes to the attribution of nationality system extended nationality to this population. This modification was one of a series of specific measures aimed at transnational linkage or reincorporation.

Promoting dual nationality: For the DGAC officials in La Paz, the goal is to extend this right to Bolivians abroad who were never aware that the possibility existed. The New Constitution of Bolivia (NCPE, its Spanish acronym) drafted in 2007, modified in 2008 and enacted in 2009 - establishes that Bolivians shall not forfeit their nationality if they marry foreigners or acquire foreign citizenship in some other way. Similarly, foreigners who acquire Bolivian nationality shall not be forced to renounce their original citizenship (NCPE, Article 142, Sections I and II). In this regard, current legislation retains stipulations from Supreme Decree 27,698 of 2004, which put into force Article 39 of the Constitution in effect at that time on "dual nationality and the recovery of Bolivian nationality". Yet beyond the legal precedents, the recent initiatives established that dual nationality could include social classes that had been previously excluded from the consular model, since mainly professionals and students had access to this in the past. Now 
efforts are made to also inform migrant workers of this possibility. As a result, between the mid-2000s and 2012, the Bolivian Consulate in Buenos Aires witnessed a gradual increase in the number of queries on obtaining dual nationality.

Facilitating documentation of Bolivians outside the country: Several measures have been taken to facilitate the documentation of Bolivians abroad and making it easier for them to get their documents as part of what was referred to as "immigration policy" in the Foreign Affairs Ministry's 2007 report (MREyC 2007). One example is Supreme Decree 28,709 (signed in May 2006 and renewed in 2008 by Supreme Decree 29,875) which ensured that Bolivians with an irregular immigration status in Argentina could get the Bolivian documentation they needed to file for residency. The decree established a flat fee of three U.S. dollars for each certificate requested. Consulates could access and consult the database of the Bolivian Civic Centre, issue birth certificates and enter information on certificates issued by the Consulate. In Spain, the most important step was the creation of the Bolivian Consular Agency, which was designed to facilitate the documentation required for regularization in this country. The Mobile Consulates programme (MRE and IOM 2011) was one of several measures designed for "co-nationals abroad" as part of Sector Development Plan 2009-20 of the Ministry of Foreign Relations.

Acknowledging the right to vote abroad: After several obstacles were overcome and a range of actors both within Bolivia and abroad got involved, mounting political pressure led the government to allow a certain number of Bolivians abroad to vote in the 2009 elections. The NCPE had already established the right to vote abroad, but the question was how to put this into practice. ${ }^{6}$ In February that year, Supreme Decree 29,894 stipulated that the electoral board would arrange the vote abroad for that year's presidential elections. Four receiving countries (Argentina, Spain, Brazil and the United States) were included in the initiative that year and it was stipulated that the number of voters abroad could not exceed six per cent of the Bolivian electoral roll. When the vote abroad was repeated in the October 2014 election, this limit was eliminated. After registering, Bolivians age eighteen and over voted in sixty-nine cities in thirty-three countries that year. Thus, "a right that more directly reflects the belonging of the immigrant in the political community of his or her country of origin" (Lafleur 2012, 24) had materialized.

\section{The new constitution and automatic jus sanguinis}

Along with other transcendental changes to the previous constitution, the NCPE modified the definition of Bolivian nationality, stipulating in Article 141 that "People born in Bolivian territory [...] and people born abroad to a Bolivian mother or father are Bolivians by birthright". What is important 
here is that the article establishes this second as automatic, that is, the children of Bolivians abroad shall automatically be Bolivian even if they have not filed any paperwork. In juridical terms, this establishes a combined system for nationality based on both jus soli and jus sanguinis.

The drawback to this amendment is that it keeps the sons and daughters of Bolivians born in Spain from easily obtaining Spanish nationality. According to the Spanish Civil Code, the sons and daughters of Spaniards are Spaniards in accordance with jus sanguinis, and the sons and daughter of foreigners take their parents' nationality. However, until the new Constitution was enacted, a child protection clause that seeks to ensure that no child is left stateless had allowed the sons and daughters of Bolivians born in Spain to acquire Spanish nationality. According to the previous Bolivian Constitution, anyone born in Bolivia was Bolivian, and children born to one or more Bolivian parents abroad could become Bolivian nationals if their parents filed at the corresponding consular office. This is how it was possible for such children to obtain Spanish nationality: the parents did not register their son or daughter at the Bolivian Consulate and as a result, the child was not Bolivian. Thus, with a consular certificate confirming that their children had not filed for Bolivian nationality, parents filed to obtain Spanish nationality for their child based on presumption and said nationality was granted immediately to prevent the child from remaining stateless.

As a result of the reformulation introduced by the NCPE, parents can no longer simply opt out of filing for their children's nationality, which is granted automatically. As a result, the civic centres in Spain determined that the children of Bolivians could no longer apply for Spanish nationality based on presumption. Now Bolivian parents seeking Spanish nationality for their offspring must wage a legal battle in order for their children to be Spanish nationals. First they must establish legal residence in Spain by presenting the child's passport, birth certificate and a registration certificate, besides certifying the parents' legal residence in Spain. Once the child has qualified for residence, the parents can file for their Spanish nationality, which requires not only the documents listed above but also proof of income.

Thus, a linkage measure initiated by the Plurinational State of Bolivia for residents abroad - designed in principle to guarantee protection and to simplify the access to their rights as Bolivians - has created obstacles for these residents if they want to file for rights and protection in Spain and all Europe. Ultimately, the amendment is thus in line with stricter immigration policies in the European Union (EU), a paradoxical turn of events since President Evo Morales was the first and most forthright Latin American leader to speak out against the EU "Return Directive", passed in 2008.

These policies and measures bring up the question of what it means to belong to a certain political community. Defining who is part of a community and how to include community members is essential to the working of nation 
states. What does this mean for a state's linkage with nationals living abroad? Clearly there is a question of numbers at stake here and, as Besserer argues in his discussion of the social uses of demographic data, "counting is a political act" $(2013,273)$. When asked about these policies and actions, the DGAC official I interviewed in March 2012 noted the state's concern over the "loss of population" and the reduction in "our population's capacity for growth" as immigrants acquire other nationalities and "the ties are lost". In this regard, when the International Organization for Migration (IOM) was drafting the Migration Profile for Bolivia, ${ }^{7}$ the DGAC officials who had access to the study's initial results questioned the numbers before it was released. The actual number of Bolivians living abroad was much higher than what the IOM stated, the officials argued.

The question of numbers is fundamental because actors bring these numbers to the negotiating tables where decisions are made on financial assistance, institutional support and budget allocations. These negotiations often involve migrant associations and other third sector organizations, entities such as the IOM and state bureaus like the DGAC, which is part of the Ministry of Foreign Relations. At the same time, the DGAC also competes for a place on the agenda with other state entities that also need funding like the National Migrations Services (SENAMIG, its Spanish acronym), which is part of the Government Ministry (Domenech 2009). The battle of the numbers, however, often involves deeper issues that go beyond instrumentality. The crux of the dispute is not how many Bolivians are abroad: it is about who is Bolivian and who could eventually be Bolivian - and how.

\section{Blood ties}

The fact that nationality is automatic is no minor detail. Nyers (2006) notes that the "accidental citizen" is the abject version of other citizens, who are presumed essential. Accidental citizenship is nominal (not necessary), ephemeral (not essential) and dangerous (undesirable). ${ }^{8}$ As a result of the NCPE amendment, Bolivian nationality became automatic, and thus necessary and essential; even so (or precisely for this reason), it is also dangerous, because it has become involuntary. Naturally, the attribution of nationality by origin - that is, given at birth - is never voluntary and almost always automatic (Trucco 2007, 3). Yet for Bolivian immigrants in Spain, the fact that their children have automatically been Bolivian since 2009 limited their chances for becoming Spanish nationals up until a very short time ago. Since automatic Bolivian nationality blocked the simple path to Spanish nationalization, the Bolivian nationality became undesirable. This led many Bolivians abroad to protest the measure, as we will see further on.

In Foucault's terms, the state's concern over the reduction in "the population's capacity for growth" and the resulting measure can be interpreted 
as a form of population production. Now, in order to understand the specific nature of this production and what it means for Bolivian nationality, it is necessary to focus on the trigger that establishes it as automatic, that is, to carefully think about the role that blood and descent are called upon to perform.

State interventions clearly distinguish between territory and population, at least in terms of the emphasis each receives. Measures that target emigrants aim to produce national population outside of the country's territory. In legal terms, this distinction is made by differentiating between "personal supremacy" - which is based on the bond of nationality and where the State is free to exert power over those it considers nationals, even if such individuals are abroad - and "territorial supremacy" - in which the State can exert power over foreigners who are "within the sphere in which the state exercises its territorial sovereignty" (Trucco 2007, 1). Incidentally, immigration policies and other measures which have some effect on the circulation of the population represent "one site in which the distinction between the inside and the outside is reproduced" (Kalm 2008, 18). Today, even sovereignty could have "more to with life, with being in time, than it does with the freezing of human life in territorial space" (Walker 2004, quoted in Nyers 2006, 36).

With the automatic application of jus sanguinis abroad, Bolivia - like other countries - exercises a sort of personal supremacy outside its territory upon those who are not yet nationals, those who are nationalized at birth or, in any case, anticipates the application of jus sanguinis on those who have yet to be born abroad. The state anticipates the production of a national population, channelling its personal supremacy in the flow of blood ties and descent.

The global historical context allows us to gain a broader understanding of this process by showing how arguments progressively emphasized blood ties as the basis for obtaining nationality and citizenship. In an investigation into the acquisition and loss of nationality in fifteen European states, Bauböck et al. (2006) emphasize the tendency - albeit with certain mitigating factors towards "more restrictive naturalisation policies" (23), which include difficult language and "integration" exams for "second generations" 9 and barriers to acquiring nationality through marriage or through extending nationality to spouses. Although Joppke considers that it is "misleading" to speak of a general shift towards more restrictive policies, he acknowledges that restrictions have gradually increased and mentions the limitations of jus soli in certain European countries in the past few decades (2008).

What is interesting is that these restrictions on immigrants who wish to obtain nationality and citizenship coincide with consolidated bonds of nationality and citizenship among "nationals residing abroad" that the same authors have described in France, Italy, Spain, Holland, Austria, Finland and other countries. The arguments for consolidating such bonds are blood ties, just 
as we saw in the Bolivian policy. While "the ties of soil and socialisation are generally downgraded [...] the ties of blood and filiation are upgraded" (Joppke 2008, 153). Both Bauböck et al. (2006) and Joppke (2008) use the term "re-ethnicisation" to refer to these transnational linkage policies of European states, the flip side to the policies that create obstacles for the immigrants within their territory. These two tendencies, which could appear contradictory, are correlates from a perspective that emphasizes blood ties.

A decade earlier, Stolcke analysed how the laws of nationality in certain European countries were becoming increasingly oriented towards blood ties. Over the course of the nineteenth century, claims Stolcke, French legislation shifted from the birthplace principle to the principle of descent and by 1880 patrilineal jus sanguinis has taken priority in both France and Germany. Great Britain would make the change a century later when, in 1981 , the fear of "colonial vengeance" led the country to impose tight limits on unconditional jus soli (Stolcke 1997, 71). Stolcke notes that over the course of this period, an essential and primordialist conception of nation is formed, and "rather than an outcome of modern state-formation, nationality [is] construed as the very foundation of the nation state" $(1997,72)$.

According to Glick Schiller and Fouron, transnational policies are "built on a concept of national identity rooted in concepts of blood and descent" (1999, 343). In a later article, Glick Schiller took this idea a step further, exploring how metaphors of blood have come and gone in relation to the nation and national belonging. One of the outstanding cases the author explores is the way in which such metaphors were used under Nazism. In the years after the National Socialism's defeat in the Second World War, the parallel between race and nation and the appeal to blood in nationalist rhetoric were generally discredited throughout Europe. Yet in the author's reconstruction, it is useful to highlight the idea of "an indelible link between nation and race that was, by the 1930s, a global ideology" (Glick Schiller 2005, 296). In the era of globalization, the use of these metaphors as part of "long-distance nationalisms" differs from the ones described by Glick Schiller in several ways. First, there are no appeals to construct the homeland but to extend "the domain of the state to wherever its members reside" (Glick Schiller $2005,297,2010)$. Yet it is clear that the metaphors share - at the very least - a family resemblance.

In Europe, there is a renewed debate on the risks of jus sanguinis and the "ethno-national rules of citizenship", in a context where "all countries [...] enforce provisions of ius sanguinis" (Dumbrava 2015a, 297). The history of jus sanguinis and the metaphor of blood date back centuries, and its meaning has changed over time. According to Marotta, this principle is rooted in ancient Roman law: concepts of marriage, legitimate kinship and citizenship were closely connected to state institutions in ancient times. The phrase "jus sanguinis" appears in a written text for the first time in the 
twelfth century; later on, jus soli becomes predominant in Europe (Marotta 2014). When France re-establishes jus sanguinis as the predominant principle after the revolution, the aim was to modernize French citizenship "by discarding feudal practices such as ius soli" (Dumbrava 2015b, 1). Over the course of the nineteenth century, the ideological tenets of the Blut und Boden were incorporated to this principle (Marotta 2014), laying the groundwork for its association with other metaphors of blood by different nationalist movements in the twentieth century.

In the same way that blood metaphors are not necessarily reactionary, although they have been used to justify genocides and oppressions (Glick Schiller 2005), the jus sanguinis principle is not intrinsically "racial" or "ethnic", although it can be used to promote ethno-nationalist or racial conceptions of belonging. "Despite being a technical and legalistic principle, jus sanguinis carries significant ideological connotations, among which the myth of commonality of blood or ethnic descent is often prevalent" (Dumbrava 2015c, 46). ${ }^{10}$

\section{Reactions to such measures and remaining questions}

Some scholars have emphasized the importance of the migrants and their organizations in these linkage policies among sending states. As Smith and Bakker have noted, "pressures from migrant organisations were also a key element in (...) the new forms of state-migrant relations that emerged over the last two decades" $(2008,7)$. In relation to the Bolivian government's recent measures associated with nationality, however, the most common reaction among Bolivians living in Spain was astonishment and anger. Beyond the pressure by migrant association for certain specific rights, like the right to vote abroad, it was clear from the beginning that the constitutional amendment did not consider the interests of Bolivian immigrants, at least not those living in Spain.

The effects of this reformulation of Bolivian nationality for Bolivian immigrants in this country led many to try to avoid the negative effects of the amendment. Those who realized how the change could affect them expressed their anger and opposition; the local office of the National Ombudsman in Madrid was flooded with requests for more information on the topic by Bolivian residents. Many blamed the new status quo on the Spanish government. According said a source at the Ombudsman in Madrid in May 2012, "The catch phrase here was 'Zapatero ${ }^{11}$ is to blame."'

Bolivian state officials also reacted. Vice-Chancellor Hugo Fernández noted that the new Bolivian Constitution had been misinterpreted and that they were working with the Spanish government to resolve the "legal issue that resulted from the constitutional amendment". Waldo Albarracín, the Ombudsman of Bolivia, added that "Spain cannot restrict the rights of people who live 
in Spanish jurisdiction on the basis of laws passed by other countries" (Los Tiempos 2009).

The Bolivian government also implemented new measures to try to help Bolivians in this situation. One such measure was to enable the Bolivian consulates to issue certificates of non-registration for minors born in Spain after the constitutional reform (at the parents' request). Bolivian parents then used these certificates as documentary evidence when filing for Spanish nationality based on presumption for their children at the civic centres of Spain. The Bolivian embassy also issued formal statements that clarified that the NCPE "does not have an implicit mandate" of nationality and that it recognizes "the right to dual nationality and parents' discretion to exercise said right" (Spanish Ministry of Justice 2012, 20). The resolutions by the Directorate General of Registries and Notary Services of Spain in March 2012 address a number of the requests filed in 2009 and later appealed or challenged by the parties. The criterion of the Directorate General is unequivocal: children born to Bolivian parents in Spain before the entry into force of the NCPE are accepted as Spaniards jure soli but those born after its entry into effect are not considered Spaniards due to the fact that they have the right to their parents' Bolivian nationality. The directorate's argument rests on the fact that the Bolivian Constitution adopts "the jus sanguinis principle for nationality" in which parents do not have a right to determine whether or not their children will receive this nationality, since filing for the child's nationality has become a mere formality (Spanish Ministry of Justice 2012, 20-21).

Certainly, the consequences of distance linkage policies are far from homogenous. This is not only because like any state policy, they apply to a diverse set of actors and circumstances, but also because these specific actions affect populations that are governed by the specific legal frameworks of their respective place of residence. In this way, for example, just as the automatic nationality imposes a limitation in the case of Bolivians in Spain, it virtually means automatic dual nationality (and dual citizenship) in a country like Argentina, where jus soli is the principle of nationality law. As a result, automatic nationality can provide some relative advantages in this country.

A set of measures initiated by a migrant-sending state like Bolivia places emigration on the country agenda and proposes "support for 'transnational life'" (MRE and IOM 2011, 21) in a context of state transformation, policies of decolonization and the reduction of inequalities. What consequences will such measures then have and what reactions will they provoke? At present, in the case analysed here, the reactions about automatic nationality were overwhelmingly negative: in all interviews I conducted among both Bolivian migrants in Spain and state officials alike, no one voiced staunch approval for the measure. Notwithstanding, this is a pending question because it deals with a social process: it remains to be seen whether men and women will adapt to this new framework. Similarly, the question of what specifically 
motivated these measures has yet to be addressed. Beyond the principal reasons for a state to want to maintain connections to its citizens abroad remittances, human capital upgrading for the migrants who could return, and political lobbying in their new country (Bauböck 2002), there are other hypotheses. One of these is related to the Bolivian state's history in relation to emigration, specifically the continuities between the current discourse of the EPB and previous state measures directed at "depopulation", a concern of the Bolivian state (Domenech and Magliano 2007, 10). Another is related to the internationalization or transnationalization of migratory policy, and the relative vulnerable position of the state apparatuses of many sending states in this global regime (Glick Schiller 2007). Yet neither of these hypotheses explains why a state would implement automatic jus sanguinis, as none of the objectives listed here ultimately requires it: all could be attained without resorting to this specific principle.

Beyond the questions that remain, there is no doubt that the framework has changed and that the change seems to be in keeping with the general guidelines on migration that other states have established in the international context. These guidelines are characterized by an intensified rhetoric of blood to speak about the nation or the use of blood descent as a way to produce population.

\section{Conclusions}

In the current social context of spatial mobility, states have taken more actions geared towards populations in movement. As a result of these actions, one of the characteristic features of states since the nineteenth century has been reworked: a country is no longer defined only by its territory but also by "the mass of the population, with its volume, its density" (Foucault 2006, 137) and the dynamics of circulation that affect it. Flows in general - but particularly population flows - are a distinguishing feature of the times and guide state interventions. This is about much more than allowing or obstructing circulation. It is about defining this flow, "encoding" it to use Deleuze and Guattari's term (1974), about establishing the categories for understanding it, acting on it, channelling it and organizing it.

In analysing informal and everyday citizenship practices in a global context in which the nation state competes with numerous alternative spheres for the definition of rights, obligations, affiliations and identities, Sassen warns of a change in the relationship between citizenship and nationality, identifying denational and postnational forms this relationship may take (Sassen 2002). Linkage policies with "nationals abroad" like those carried out by the EPB reveal mechanisms that strengthen the ties between citizenship and nationality without denying the existence or growth of such alternative forms of citizenship or the emancipation of such citizenship practices from nationality. 
Automatic jus sanguinis will have direct effects (positive in Bolivia, negative in certain countries where emigrants reside) in the exercise of citizen rights.

On the other hand, the case examined here shows that the mobile population is encoded in metaphors of blood and descent. Population flow is understood as analogous to blood flow. For the children of Bolivian abroad, this encoding means nationality by birthright without any need to file paperwork, eliminating the possibility that another administrative procedure could lead someone down other paths and produce different results. Nationality and citizenship are mounted on descent and seem to become as essential as the way blood itself is usually interpreted and as the way biologized family ties are usually experienced.

This movement ratifies a tendency worldwide towards a strong encoding of the bonds of national belonging in terms of blood ties. As some scholars have recently noted, "the unconditional application of ius sanguinis abroad and differentiated privileges regarding admission to, exercise of, loss and reacquisition of citizenship, could [...] be interpreted as driven by or reinforcing ethno-national conceptions about state membership" (Dumbrava 2015a, 307).

One of the questions that remains to be addressed is whether in the years to come this trend of encoding the flows and bonds of nationality for these populations will persist. On the other hand, there are historical and conceptual questions about how the use of blood metaphors will evolve. Different alternatives appear on the horizon between the "re-ethnicization" that certain authors speak of and the potential reconstruction of racialist logics.

Certain lessons from modern history force us to remain alert to the ways in which concepts of race and nation can be related and as to which discourses surrounding blood and descent can foster racism, xenophobia and cultural fundamentalism. While we are used to critically thinking about these problems from the side of immigrant-receiving countries for many reasons, it also seems relevant to critically examine them from the side of sending countries in their search to connect with those who migrate. The congealing of the blood rhetoric can lead to rigid, exclusionary frameworks that are used to formulate institutional policies directed at residents abroad, and to contemplate and act out nationalities and citizenships.

\section{Notes}

1. The data are taken from an ethnographic approach and a work based on secondary sources. In terms of fieldwork, I made visits, attended meetings and conducted unstructured individual and group interviews with migrants and members of government bureaus and offices and non-governmental associations that worked on immigration issues in La Paz and El Alto, Bolivia between February 2010 and March 2010, and during the first half of 2013 (39 interviews); in Madrid, Spain, during the first half of 2012 (27 interviews) and 
in Buenos Aires, Argentina, between April and August 2010 and during the first half of 2013 (31 interviews). The broader research questions that motivated this study surround the way in which different actors participate in the process of social construction (definition and categorization) of "migration" and of the "migrants") (Feldman-Bianco et al. 2010).

2. Nina Glick Schiller provides a systematic overview of this type of policies in countries like Mexico, Colombia, the Dominican Republic, the Philippines, Eritrea, India, Croatia, Ecuador, Brazil, Portugal and Haiti during this decade. As a historic precedent, the author mentions different sending countries Hungary, Italy, Japan and China - that implemented policies like these before the Second World War (Glick Schiller 2005, 2010).

3. On the possible uses of these works by Foucault in immigration studies, see Walters (2015).

4. These include supranational organizations like the United Nations, which formed the Global Migration Group (Kalm 2008); regional intergovernmental bodies such as UNASUR, which works actively in categories such as that of "South American citizenship"; other international entities and non-governmental organizations.

5. More specifically, it is important to note that among the different countries, in spite of the similarities, there are minor differences in the definition of each concept and in the way the concepts are related. The EUDO Citizenship observatory offers some interesting conceptual precisions about nationality and citizenship, and provides insightful European and American country profiles about citizenship laws and policies (http://eudo-citizenship.eu/). In the case of the concept of "nationality", it is important to distinguish between its legal and sociological uses. In this article, I limit myself to the social and institutional implications of the legal definition of nationality and of the policies associated with it.

6. For an account on the process that ended with the approval of voting abroad, see Lafleur (2012, 53 and SS).

7. Since 2007 , the IOM has drafted country profiles, emphasizing the importance of "reliable numbers" in the "management" of international migration. The publication date on the Migration Profile for Bolivia is November 2011 but when I was conducting fieldwork in La Paz during the first few months of 2012, the document was not yet publically available.

8. "Accidental citizenship" is a term that institutional actors, politicians and journalists began using to make arguments against jus soli in the United States after 11 September 2001.

9. Some authors concur that the increase in requirements suggests a shift from naturalization as a tool for integration to naturalization as the end to a successful integration (Bauböck et al. 2006; Joppke 2008; Gil Araújo et al. 2010).

10. It is noteworthy that contemporary authors that defend jus sanguinis argue that the principle alludes to the "natural fact of kinship" and "natura as a basis for veritas (naturae veritas)". They highlight that in Italian law post-unification, jus sanguinis did not make reference to racial purity or have any racial connotations but instead aimed to perpetuate "the legacy of the homeland", and "thus strive towards a sort of non-imperialist, peaceful colonization of the world" (Marotta 2014, 693-694).

11. José Luis Rodríguez Zapatero, president of Spain from April 2004 to December 2011. 


\section{Disclosure statement}

No potential conflict of interest was reported by the author.

\section{References}

Basch, Linda, Nina Glick Schiller, and Cristina Szanton Blanc. 1994. Nations Unbound. Transnational Proyects, Postcolonial Predicaments, and Deterritorialized NationsStates. Amsterdam: Gordon and Breach.

Bauböck, Rainer. 2002. "Towards a Political Theory of Migrant Transnacionalism." IWE Working Paper Series, Núm. 34, 1-17, Vienna.

Bauböck, Rainer, Eva Ersbøll, Kees Groenendijk, and Harald Waldrauch. 2006. "Introduction." In Acquisition and Loss of Nationality. Policies and Trends in 15 European States. Volume 1: Comparative Analyses, edited by Rainer Bauböck, Eva Ersbøll, Kees Groenendijk, and Harald Waldrauch, 15-34. Amsterdam: Amsterdam University Press.

Besserer, Federico. 2013. "Micropolíticas de la diferencia en una comunidad transnacional." In Hegemonía cultural y políticas de la diferencia, edited by Alejandro Grimson and Karina Bidaseca, 263-278. Buenos Aires: CLACSO.

Bourdieu, Pierre. 1982. Ce que parler veut dire. L'économie des échanges linguistiques. Paris: Fayard.

Brubaker, Rogers. 1992. Citizenship and Nationhood in France and Germany. Cambridge: Harvard University Press.

Deleuze, Gilles, and Felix Guattari. 1974. El Antiedipo. Capitalismo y esquizofrenia. Buenos Aires: Corregidor.

Domenech, Eduardo. 2009. "Avatares de la política migratoria en Bolivia: el Estado y los emigrantes como nacionales en el exterior." In Migraciones contemporáneas. Contribución al debate, edited by Cecilia Salazar, 259-288. La Paz: CAF, CIDESUMSA, Plural editores.

Domenech, Eduardo, and María José Magliano. 2007. "Migraciones internacionales y política en Bolivia: pasado y presente." Estudios Migratorios Latinoamericanos, 21 (62): 3-41.

Dumbrava, Costica. 2015a. "Super-foreigners and Sub-citizens: Mapping Ethno-national Hierarchies of Foreignness and Citizenship in Europe." Ethnopolitics 14 (3): 296-310.

Dumbrava, Costica. 2015b. "Kick Off Contribution: Bloodlines and Belonging: Time to Abandon lus Sanguinis?" In Bloodlines and Belonging: Time to Abandon lus Sanguinis?, edited by Costica Dumbrava, and Rainer Bauböck, EUI Working Paper RSCAS 2015/80, 1-5. Fiesole: European University Institute.

Dumbrava, Costica. 2015c. "Don't Put the Baby in the Dirty Bathwater! A Rejoinder." In Bloodlines and Belonging: Time to Abandon lus Sanguinis?, edited by Costica Dumbrava, and Rainer Bauböck, EUI Working Paper RSCAS 2015/80, 46-50. Fiesole: European University Institute.

Feldman-Bianco, Bela, Liliana Rivera Sánchez, Carolina Stefoni, and Marta Inés Villa Martínez, comps. 2010. La construcción social del sujeto migrante en América Latina. Prácticas, representaciones y categorías. Quito: FLACSO-Ecuador, CLACSO, U. Alberto Hurtado.

Foucault, Michel. 2006. Seguridad, territorio, población. Buenos Aires: Fondo de Cultura Económica.

Foucault, Michel. 2007. Nacimiento de la biopolítica. Buenos Aires: Fondo de Cultura Económica. 
Gil Araújo, Sandra, Aurora Álvarez, Alberto Arribas, Nayra García, and Begoña de la Fuente. 2010. "Interrogar la ciudadanía desde la inmigración. Idearios sobre integración, inmigración y ciudadanía en el ámbito político español." In Mediterráneo migrante. Tres décadas de flujos migratorios, edited by Carlos De Castro, 242-264. Murcia: Universidad de Murcia.

Glick Schiller, Nina. 2005. "Blood and Belonging: Long-distance Nationalism and the World Beyond." In Complexities. Beyond Nature and Nurture, edited by Susan McKinnon and Sydel Silverman, 289-312. Chicago: The University of Chicago Press.

Glick Schiller, Nina. 2007. "Beyond the Nation-State and Its Units of Analysis: Towards a New Research Agenda for Migration Studies." In Essentials of Migration Theory, Working Paper 33, 1-42. Bielefeld: COMCAD - Center on Migration, Citizenship and Development.

Glick Schiller, Nina. 2010. "Long Distance Nationalism and Peripatetic Patriots." In Transnational Migration, Cosmopolitanism and Dis-located Borders, edited by Bruno Riccio and Chiara Brambilla, 27-52. Bergamo: Guaraldi.

Glick Schiller, Nina, and Georges Fouron. 1999. "Terrains of Blood and Nation: Haitian Transnational Social Fields." Ethnic and Racial Studies 22 (2): 340-366.

Guang, Tian, and Mahesh R. Debata. 2010. "Identity and Mobilization in Transnational Societies: A Case Study of Uyghur Diasporic Nationalism." China and Eurasia Forum Quarterly 8 (4): 59-78.

Guarnizo, Luis Eduardo, and Michael Peter Smith. 1998. "The Locations of Transnationalism." In Transnationalism from Below, Special Edition of the Journal of Comparative Urban and Community Research, edited by Michael Peter Smith and Luis Eduardo Guarnizo, Vol. 6, 3-34. New Brunswick: Transaction.

Hall, Stuart. 2003. Da diáspora. Identidades e Mediações Culturais. Belo Horizonte: Ed. UFMG.

Hinojosa Gordonava, Alfonso, Eduardo Domenech, and Jean-Michel Lafleur. 2012. "Surgimiento y desarrollo del 'voto en el exterior' en el 'proceso de cambio' boliviano." In Diáspora y voto en el exterior. La participación política de los emigrantes bolivianos en las elecciones de su país de origen, edited by Jean-Michel Lafleur, 39-63. Barcelona: CIDOB edicions.

Joppke, Christian. 2008. "Comparative Citizenship. A Restrictive Turn in Europe?" Law \& Ethics of Human Rights 2: 128-168.

Kalm, Sara. 2008. "Governing Global Migration." Lund Political Studies, No. 153, Department of Political Science, Lund University.

Kivisto, Peter, and Thomas Faist. 2007. Citizenship: Discourse, Theory, and Transnational Prospects. Malden, MA: Blackwell.

Lafleur, Jean-Michel. 2012. "Introduction. Transnacionalismo, diáspora y voto en el exterior." In Diáspora y voto en el exterior. La participación política de los emigrantes bolivianos en las elecciones de su país de origen, edited by Jean-Michel Lafleur, 15-37. Barcelona: CIDOB edicions.

Levitt, Peggy, and Nina Glick Schiller. 2004. "Perspectivas internacionales sobre migración: conceptualizar la simultaneidad." Migración y Desarrollo 3: 60-91.

Los Tiempos. 2009. "Gobierno cree que España malinterpretó la CPE." July 9. Accessed 20 October 2015. http://www.lostiempos.com/diario/actualidad/nacional/20090709/ gobierno-cree-que-espana-malinterpreto-la-cpe_24411_38190.html

Marotta, Valerio. 2014. "Ius sanguinis, ius soli: una breve nota sulle radici storiche di un dibattito contemporáneo." Periodica 103: 663-694. 
MRE and IOM (Bolivian Foreign Affairs Ministry and International Organization for Migration). 2011. Bolivianos y bolivianas en el exterior: Propuestas de política pública y Ley para las migraciones. La Paz: IOM Bolivia.

MREyC (Ministry of Foreign Affairs and Worship). 2007. "2007 Administration Report." Accessed 7/12/2015. http://www.rree.gob.bo/webmre/publicaciones/d80.pdf

Nyers, Peter. 2006. "The Accidental Citizen: Acts of Sovereignty and (Un)making Citizenship." Economy and Society 35 (1): 22-41.

Ortner, Sherry. 2006. Anthropology and Social Theory. Culture, Power, and the Acting Subject. Durham: Duke University Press.

Sassen, Saskia. 2002. "The Repositioning of Citizenship: Emergent Subjects and Spaces for Politics." Berkeley Journal of Sociology 46: 4-25.

Silverman, Max. 1992. Deconstructing the Nation. Immigration, Racism and Citizenship in Modern France. London: Routledge.

Smith, Michael Peter, and Matt Bakker. 2008. Citizenship across Borders. The Political Transnationalism of El Migrante. Ithaca, NY: Cornell University Press.

Smith, Michael Peter, and Luis Eduardo Guarnizo. 2009. "Global Mobility, Shifting Borders and Urban Citizenship." Tijdschrift voor Economische en Sociale Geografie 100 (5): 610-622.

Solomon, M. Scott. 2009. "State-led Migration, Democratic Legitimacy, and Deterritorialization: The Philippines' Labour Export Model." European Journal of East Asian Studies 8 (2): 275-300. doi:10.1163/156805809X12553326569759.

Spanish Ministry of Justice. 2012. Ministry of Justice Bulletin. Resolutions of the Directorate General of Registries and Notary Services. Madrid: Technical Secretariat. Center of Publications.

Stolcke, Verena. 1997. "The «Nature» of Nationality." In Citizenship and Exclusion, edited by Veit Bader, Chap. 3, 61-80. Londres: Macmillan Press.

Stolcke, Verena. 1999. "La nueva retórica de la exclusión en Europa." International Social Science Journal - ISSJ . LI (159). http://www.unesco.org/issj/rics159/stolckespa.html.

Trucco, Marcelo. 2007. "La nacionalidad en el derecho internacional. Régimen jurídico de la nacionalidad argentina" on Infojus. Sistema Argentino de Información Jurídica, Argentine Ministry of Justice and Human Rights. Accessed 16 October 2015. http:// www.infojus.gob.ar/doctrina/dasf070028-trucco-nacionalidad_en_derecho_ internacional.htm

van Dongen, Els. 2017. "Behind the Ties that Bind: Diaspora-making and Nation-building in China and India in Historical Perspective, 1850s-2010s." Asian Studies Review 41 (1): 117-135. doi:10.1080/10357823.2016.1264363.

Walters, William. 2015. "Reflections on Migration and Governmentality." Movements. Journal für kritische Migrations- und Grenzregimeforschung 1 (1): 1-30. 